\title{
Możliwość nagrywania i publikowania zdjęć ze spotkań z posłem ${ }^{1}$
}

\begin{abstract}
The admissibility of recording and publishing photographs from meetings with a Deputy: In the author's opinion, a consent to distribute the image of a person is not required in several cases. Firstly, if it is only a detail of the whole image, e.g. of a public gathering or event. Secondly, if it is an image of a well-known person when the picturei refers to its public functions. It is also allowed to publish images of pedestrians or people assembled in a street demonstration. However, if the dominant feature of the frame is the image of a particular person, the dissemination of the picture requires the consent of such person, granted in any form.
\end{abstract}

Keywords: Deputy, copyright law, image

Słowa kluczowe: poseł, prawo autorskie, wizerunek

Radca prawny, ekspert ds. legislacji BAS - joanna.karolczak@sejm.gov.pl • https://orcid.org/0000-0002-5421-4683

\section{Przedmiot opinii}

Opinia dotyczy prowadzenia dokumentacji spotkań otwartych z posłem. Zagadnienia wymagające wyjaśnienia zostały sformułowane następująco: Chodzi o wytyczne i zakres relacji foto, video i live stream ze spotkań, na które zapraszany jest, czy też które organizuje poseł. Spotkania maja charakter otwarty i odbywaja się $w$ różnych miejscach $w$ całej Polsce - najczęściej w pomieszczeniach zamkniętych. W jakim zakresie można publikować (np. na Facebooku i stronie www posła):

- zdjęcia ze spotkań

- relacje video ze spotkań

- transmisje (live stream)?

1 Opinia prawna dotyczaca możliwości nagrywania i publikowania zdjęć ze spotkań z posłem sporządzona 16 maja 2018 r. na zlecenie Klubu Parlamentarnego Platforma Obywatelska; BAS-WAP 865/18. 
Jak możemy rozwiązać ten problem od strony prawnej - czy np. przez umieszczenie informacji o relacjonowaniu spotkania np. na drzwiach jest wystarczajace? Jaka powinna być treść takiej informacji, czy np. „spotkanie jest relacjonowane”? Czy jest całkowita dowolność $w$ relacjonowaniu tych spotkań?

Czy istnieja jakieś ograniczenia przy robieniu i publikowaniu zdjęć - np. poseł może być tylko sam na zdjęciu? Czy może fotografować się z uczestnikami spotkania? Ile osób musi być na zdjęciu, żeby był to "ttum” - wg terminologii ustawy o prawie autorskim. Jakie zdjęcia może robić i publikować, a jakich nie? Jeśli chodzi o video, co można nagrywać, a czego nie (na sali, podczas spotkania). Czy konieczna jest jakaś informacja o relacji wideo? Czy można nagrywać ludzi, którzy zadaja pytania? Czy np. tylko posła? Czy tak samo jest jeśli chodzi o obraz i dźwięk? Poproszono także aby poza analiza przepisów $w$ opinii znalazły się praktyczne informacje odnoszace się do organizacji spotkań z zachowaniem prawa.

Opinię sporządzono na podstawie:

- ustawy z 4 lutego 1994 r. o prawie autorskim i prawach pokrewnych, t.j. Dz.U. 2017, poz. 880, ze zm., dalej: prawo autorskie,

- ustawy z 23 kwietnia 1964 r. - Kodeks cywilny, t.j. Dz.U. 2017, poz. 459, ze zm.,

- ustawy z 26 stycznia 1984 r. - Prawo prasowe, Dz.U. nr 5, poz. 24, ze zm.

Opinia uwzględnia stan prawny na dzień 9 maja 2018 r.

\section{Uzasadnienie prawne}

1. Zgodnie $\mathrm{z}$ art. 81 ust. 1 prawa autorskiego rozpowszechnianie wizerunku wymaga zezwolenia osoby na nim przedstawionej. W braku wyraźnego zastrzeżenia zezwolenie nie jest wymagane, jeżeli osoba ta otrzymała umówioną zapłatę za pozowanie. W myśl ust. 2 zezwolenia nie wymaga rozpowszechnianie wizerunku:

- osoby powszechnie znanej, jeżeli wizerunek wykonano w związku z pełnieniem przez nią funkcji publicznych, w szczególności politycznych, społecznych, zawodowych,

- osoby stanowiącej jedynie szczegół całości, takiej jak zgromadzenie, krajobraz, publiczna impreza.

Wizerunek jest dobrem osobistym i podlega ochronie na podstawie przepisów Kodeksu cywilnego. Zgodnie z jego art. 23 dobra osobiste człowieka, jak w szczególności zdrowie, wolność, cześć, swoboda sumienia, nazwisko lub pseudonim, wizerunek, tajemnica korespondencji, nietykalność mieszkania, twórczość naukowa, artystyczna, wynalazcza i racjonalizatorska, pozostają pod ochroną prawa cywilnego niezależnie od ochrony przewidzianej w innych przepisach. 
2. Na wizerunek - w rozumieniu przepisów - składa się ogół zewnętrznych cech, które charakteryzują daną osobę. Wizerunek definiowany jest jako wygląd człowieka, jego podobizna, jego obraz fizyczny. W te ramy włączyć można dodatkowe elementy związane z wykonywanym zawodem, jak charakteryzacja, ubiór, sposób poruszania się, inne elementy identyfikujące, np. okulary, fryzura czy nawet szczególna linia profilu bądź charakterystyczny cień. W każdym przypadku chodzi o cechy immanentnie związane z konkretną osobą fizyczną, dla niej znamienne i pozwalające na jej rozpoznawalność. Wizerunkiem nie jest sposób postrzegania i oceny danej osoby w odbiorze zewnętrznym (jej życiorysu, cech charakteru, postępowania, utrwalonej pozycji zawodowej itp.) $)^{2}$.

W sytuacji spotkań z posłem należy uznać, że rozpowszechnianie wizerunku posła będzie spełniało kryterium określone w art. 81 ust. 2 pkt 1 prawa autorskiego, poseł jest bowiem osobą powszechnie znaną ${ }^{3}$. Dlatego filmowanie i fotografowanie posła, a następnie publikowanie zdjęć (rozpowszechnianie wizerunku) jest dopuszczalne. Natomiast co do pozostałych osób, będących na spotkaniu - niebędących osobami publicznymi czy powszechnie znanymi - to stwierdzić należy, że samo nagrywanie wypowiedzi i fotografowanie osób będących na spotkaniu nie jest objęte normą wynikającą z omawianego przepisu, który dotyczy rozpowszechniania wizerunku. Jednak w niektórych przypadkach nawet samo utrwalenie wizerunku osoby bez jej zgody może być naruszeniem art. 23 k.c. i 24 k.c. Zdaniem R. Golata: chociaż prawo autorskie mówi tylko o zezwoleniu na rozpowszechnianie wizerunku (art. 81 ust. 1 zdanie 1 ustawy o prawie autorskim), to w świetle całości regulacji ustawowej nie powinno budzić watpliwości, że zgoda dysponenta wizerunku potrzebna jest także w pozostalych przypadkach, a więc również w momencie robienia zdjęcia. Fotografowany ma

2 Wyrok Sądu Apelacyjnego w Warszawie z 22 maja 2015 r., sygn. akt I ACa 1741/14, LEX nr 1755241.

3 Pomijam w tym miejscu rozważania na temat możliwych interpretacji pojęcia „osoba powszechnie znana”, o których mowa np. w wyroku Sądu Apelacyjnego w Poznaniu z 2 września 2010 r., sygn. akt I ACa 620/10: Określona grupa osób może być $z$ góry zaliczona do grona osób powszechnie znanych $w$ rozumieniu przepisów prawa autorskiego bądź ze względu na petniony urząd, bądź wykonywany zawód (sportowcy, aktorzy, dziennikarze), szczególnie jeśli osoba go wykonująca zdobędzie popularność. $W$ szczególnych przypadkach w orbicie społecznych zainteresowań może znaleźć się tzn. zwykly człowiek jeśli będzie sprawca określonego zdarzenia a jego działania zostana odpowiednio nagłośnione, np. urządzi happening (LEX nr 756690). J. Sieńczyło-Chlabicz, sięgając do określenia „osoba publiczna”, doszła do wniosku, że jednostka może być zakwalifikowana do kręgu osób publicznych, jeżeli spełnia jedno z dwóch kryteriów: 1) kryterium wykonywania działalności publicznej w węższym rozumieniu, w szczególności pełnienia funkcji publicznych, 2) kryterium wykonywania mandatu zaufania publicznego, np. poseł, senator, radny (eadem, Naruszenie prywatności osób publicznych przez prase, Warszawa 2012, s. 242). 
prawo odmówić zgody na wykonanie zdjęcia, mimo że fotograf nie ma zamiaru go publikować. Takie stanowisko wyraził także Sąd Apelacyjny w Warszawie w wyroku z 17 sierpnia 2016 r., sygn. akt VI ACa 839/155, stwierdzając: Już samo utrwalenie wizerunku osoby bez jej zgody, jest już naruszeniem w płaszczyźnie art. 23 k.c. i 24 k.c. Natomiast rozpowszechnianie można rozważać również dodatkowo w płaszczyźnie dalszych przepisów. Również P. Ślęzak uważa, że istnieje wymóg uzyskania zgody osoby widniejącej na wizerunku na sporządzenie, a następnie na rozpowszechnianie tego wizerunku6. W literaturze wyrażono też pogląd, że naszkicowanie portretu osoby fizycznej bez jej zgody jest naruszeniem wizerunku7.

3. W trakcie transmisji spotkania, relacji czy robienia zdjęć wizerunek osób postronnych jest rozpowszechniany (publikowany). Na takie działanie potrzebna jest zgoda osób fotografowanych (nagrywanych), z wyjątkami określonymi w ustawie, czyli gdy osoba otrzymała zapłatę za pozowanie (art. 81 ust. 1) oraz gdy stanowi jedynie szczegół całości, takiej jak zgromadzenie, krajobraz, publiczna impreza, przy czym należy podkreślić, że wyliczenie to ma charakter przykładowy. W przepisie tym nie zostało użyte wyrażenie „tłum”, jak wskazano w pytaniu przytoczonym we wstępie opinii.

4. Piotr Ślęzak ${ }^{8}$ proponuje, aby „zgromadzenie” rozumieć w sposób sformalizowany jako zgrupowanie osób na otwartej przestrzeni dostępnej dla nieokreślonych imiennie osób w określonym miejscu w celu odbycia wspólnych obrad lub w celu wspólnego wyrażenia stanowiska w sprawach publicznych (art. 3 ust. 1 ustawy z 24 lipca 2015 r. - Prawo o zgromadzeniach, t.j. Dz.U. 2018, poz. 408), zaś „imprezę publiczną” rozumieć jako imprezę masową w rozumieniu ustawy z 20 marca 2009 r. o bezpieczeństwie imprez masowych (t.j. Dz.U. 2017, poz. 1160, ze zm.) - są to imprezy artystyczno-rozrywkowe i sportowe - a także imprezy masowe, do których nie stosuje się tej przepisów ustawy (np. imprezy organizowane w kinach, teatrach, bibliotekach, domach kultury, szkołach, placówkach oświatowych, zawody sportowe dla dzieci, imprezy dla pracowników). Zdaniem T. Grzeszak, termin „zgromadzenie” jest nieostry - dopuszczalne jest objęcie nim każdej, większej, publicznej grupy ludzi, zaś publiczna impreza, to impreza dostępna dla niezamkniętego kręgu osób ${ }^{9}$. Skłaniałabym się do tej drugiej interpretacji - interpretacja P. Ślęzaka wydaje się nazbyt formalistyczna, tym

4 R. Golat, Zasady rozpowszechniania wizerunków pracowników, „Służba Pracownicza” 2009, nr 5(19).

5 LEX nr 2149600.

6 P. Ślęzak, Ustawa o prawie autorskim i prawach pokrewnych. Komentarz, Warszawa 2017, s. 30.

P. Sobolewski [w:] Kodeks cywilny. Komentarz, red. K. Osajda, 2018, Legalis.

P. Ślęzak, Ustawa o prawie autorskim, op. cit., s. 575.

9 T. Grzeszak [w:] System prawa prywatnego, t. 13, Prawo autorskie, red. J. Barta, Warszawa 2017, s. 825. 
bardziej że wspomniane przez niego definicje zostały ustanowione na użytek konkretnych ustaw i stosowanie ich na gruncie prawa autorskiego nie znajduje uzasadnienia, pomijając już to, że nie uzasadnił, czym kierował się, zrównując pojęcia „impreza publiczna” i „impreza masowa”.

5. Janusz Barta i Ryszard Markiewicz zauważają, że stosownie do art. 81 ust. 2 pkt 2 prawa autorskiego, dopuszczalne jest rozpowszechnianie wizerunku stanowiącego jedynie szczegół przedstawianej (np. w formie fotografii, filmu, obrazu) takiej całości, jak zgromadzenie, krajobraz, publiczna impreza. Przepis ten umożliwia prowadzenie działalności dokumentacyjnej, sprawozdawczej, a także zapewnia wolność fotografowania wydarzeń publicznych. Nie jest dozwolone rozpowszechnianie bez zgody portretowanego zarówno jego wizerunków „skadrowanych", jak i wizerunków wkomponowanych w większą całość, lecz stworzonych w warunkach naruszenia jego prawa do prywatności ${ }^{10}$.

Dla zastosowania art. 81 ust. 2 pkt 2 prawa autorskiego rozstrzygające znaczenie ma zatem ustalenie w strukturze przedstawienia relacji między wizerunkiem osoby a pozostałymi elementami jego treści. Jeśli wizerunek osoby stanowi wyłacznie element akcydentalny lub akcesoryjny przedstawienia, czyli że $w$ razie jego usunięcia nie zmieniłby się przedmiot $i$ charakter przedstawienia, to rozpowszechnianie nie wymaga zezwolenia ${ }^{11}$. Jako typowy przykład podaje się, że rozpowszechnienie wizerunku pracownika uczestniczącego w szkoleniu wymagać będzie jego zgody, jeśli wizerunek ten nie jest szczegółem większej całości, takiej jak ujęcie całej sali konferencyjnej z wizerunkami wszystkich uczestników szkolenia oraz jeśli nie jest to wizerunek osoby powszechnie znanej w rozumieniu art. 81 ust. 2 pkt 1 prawa autorskiego ${ }^{12}$. Taką samą regułę należy zastosować na spotkaniach z posłem - widok (nagranie) całej sali jest zgodny z przepisami, natomiast dokonanie zbliżenia np. na osobę wypowiadającą się do mikrofonu (zadającą pytanie) - wymaga zgody tej osoby, bowiem wtedy nie stanowi ona już „szczegółu całości”. Niewątpliwie taki charakter może mieć nagrywanie obrazu wielotysięcznej rzeszy ludzi znajdujących się w miejscu publicznym na zewnątrz kościoła w trakcie Mszy Świętej w ramach zorganizowanej pielgrzymki ${ }^{13}$. W orzecznictwie wskazuje się, że: osoba decydująca się na udział w publicznym zgromadzeniu nie tyle wyraża w sposób dorozumiany zgodę na upublicznienie jej wizerunku jako szczegółu całości, ale godzi się na to, że wizerunek taki może zostać rozpowszechniony $w$ ramach publikacji całości bez jej zgody, dorozumianej czy

10 Prawo autorskie i prawa pokrewne. Komentarz, red. J. Barta, R. Markiewicz, 2011, LEX, s. 524-525.

11 Wyrok Sądu Apelacyjnego w Warszawie z 28 lutego 2017 r., sygn. akt I ACa 2383/15, LEX nr 2265686.

12 R. Golat, Zasady rozpowszechniania, op. cit.

13 Wyrok Sądu Apelacyjnego w Katowicach z 30 września 2013 r., sygn. akt II AKa 201/13, Legalis 58121. 
nie - to nie ma $w$ tym przypadku znaczenia, ponieważ zgoda taka nie jest wymagana na podstawie regulacji ustawowej ${ }^{14}$.

Jak podaje P. Ślęzak: rozpowszechnianie wizerunku bez zezwolenia jest dopuszczalne, o ile fotograf albo operator wybieraja główny obiekt (nie jest nim wizerunek konkretnej osoby) i umieszczaja go w pobliżu punktów, które najszybciej przyciagaja wzrok odbiorcy ewentualnie wzrok odbiorcy prowadza: rzeka, pasmo górskie, droga, linia kolejowa (na takie modele kompozycji wskazuje opracowanie R.M. Sarbiński, Utwór fotograficzny i jego twórca $w$ prawie autorskim, Kraków 2004, s. 122-127). Dlatego za dozwolone należy uznać publikowanie wizerunków spacerowiczów w parku, ludzi całujacych się w plenerze, ludzi zgromadzonych $w$ czasie manifestacji ulicznej, uczestników konferencji naukowej itp. Natomiast jeżeli dominanta kadru jest wizerunek konkretnej osoby (fotograf albo operator „skupiaja się” na jednej osobie, eksponuja ja), rozpowszechnianie wymaga zgody osoby przedstawionej $w$ kadrze. Poglad taki znajduje potwierdzenie w pogladach doktryny (zob. J. Barta, R. Markiewicz, Prawo autorskie i prawa pokrewne. Komentarz, Kraków 2011, s. 632; T. Grzeszak, w: System Prawa Prywatnego, t. 13, red. J. Barta, Warszawa 2013, s. 706; D. Flisak, w: Prawo autorskie i prawa pokrewne, red. D. Flisak, s. 1152) i w judykaturze (por. wyr. SA w Warszawie z 13.1.1999 r., I ACa 1089/98, Wokanda 2000, Nr 3, s. 45; wyr. SA w Poznaniu z 30.5.2006, I ACa 246/05, niepubl.; wyr. SA w Poznaniu z 2.9.2010 r., I ACa 620/10, Legalis) ${ }^{15}$.

6. Filmowanie posła na spotkaniu $z$ wyborcami zawsze będzie dopuszczalne, ponieważ jest to osoba publiczna - nie jest wymagane zezwolenie na rozpowszechnianie wizerunku od osoby powszechnie znanej (publicznej), jeśli wizerunek odnosi się do funkcji publicznych pełnionych przez tę osobę. Publikacja wizerunku powinna być związana z relacjonowaniem pełnienia funkcji publicznych przez osobę powszechnie znana lub wykonywaniem przez nia czynności wiążących się z działalnością publiczną. Swoboda rozpowszechniania wizerunku znanej osobistości bez jej zgody wyklucza przedstawianie tej osoby w sytuacjach niezwiązanych z petnieniem funkcji publicznych (np. $w$ trakcie prac w przydomowym ogródku, podczas spacerów $z$ rodzina) ${ }^{16}$.

7. W doktrynie od lat sygnalizuje się potrzebę ochrony głosu człowieka, jako jego dobra osobistego ${ }^{17}$. Zdaniem J. Sieńczyło-Chlabicz głosu nie należy traktować jako odrębnego dobra osobistego. Powinien być on chroniony w ramach prawa do wizerunku, nie jako obraz fizyczny (wizualny) danej osoby, lecz jako jej obraz odbierany za pomocą zmysłu słuchu. Prawo osobiste do ludzkiego głosu

14 Wyrok Sądu Apelacyjnego w Łodzi z 6 października 2014 r., sygn. akt I ACa 429/14, LEX nr 1554754.

15 P. Ślęzak, Ustawa o prawie autorskim, op. cit., s. 575.

16 J. Sieńczyło-Chlabicz, Rozpowszechnianie wizerunku osób powszechnie znanych, „Przegląd Prawa Handlowego” 2003, nr 9, s. 39.

17 Szerzej na ten temat: P. Ślęzak, Ustawa o prawie autorskim, op. cit., s. 558-559. 
traktować należy jako dźwięczny wizerunek. Jednak musi być spełniony podstawowy warunek, a mianowicie wizerunek dźwięczny, czyli głos, musi być rozpoznawalny dla osób trzecich, dopiero wówczas będzie korzystał z ochrony prawnej. Oznacza to, że głos danej osoby musi być na tyle charakterystyczny i wyróżniający się, by można było wskazać konkretną osobę, od której pochodzi ${ }^{18}$. Prawo do własnego głosu (zwrotu takiego używają J. Barta, R. Markiewicz) ${ }^{19}$ można traktować jako element wizerunku ${ }^{20}$ albo jako samodzielne dobro osobiste ${ }^{21}$. Zdaniem P. Ślęzaka głos i wizerunek są odrębnymi dobrami prawnie chronionymi ${ }^{22}$. Zdaniem P. Sobolewskiego: ochrona głosu jako dobra osobistego nie powinna budzić wątpliwości. Kontrowersyjne jest jednak, czy głos stanowi odrębne dobro osobiste, jak uznat SA w Gdańsku [wyrok z 21 czerwca 1991 r., sygn. akt I ACr 127/91, OSA 1992, nr 1, poz. 8 - uzupełnienie J.M.K.], czy należy traktować go jako element wizerunku, zmieniając równocześnie jego definicję w sposób umożliwiający objęcie cech innych niż tylko wygląd fizyczny ${ }^{23}$.

8. Tak więc, jeśli planowane nagranie (transmisja) ma skupiać się tylko na tzw. szerokich planach, bez pokazywania zbliżeń poszczególnych uczestników - nie ma konieczności uzyskiwania zgody na publikowanie wizerunku. Jeśli jednak planowane są zbliżenia, np. osób zadających pytania posłowi, wtedy konieczna jest zgoda na nagrywanie tych osób.

9. Z punktu widzenia prawa autorskiego zgoda na wykorzystanie wizerunku może być udzielona w dowolnej formie, ale musi być niewątpliwa. Oznacza to, że osoba jej udzielająca musi mieć pełną świadomość nie tylko formy przedstawienia jej wizerunku, ale także miejsca i czasu publikacji, zestawienia $\mathrm{z}$ innymi wizerunkami i towarzyszącego komentarza. Zakres udzielonej zgody na wykorzystanie wizerunku powinien być w razie sporu interpretowany w sposób restryktywny. Brak jest także podstaw do przyjęcia, że zgoda na rozpowszechnianie wizerunku oznacza zgodę na naruszenie innych dóbr osobistych ${ }^{24}$. Zgody na publikację wizerunku nie domniemywa się, jednakże art. 81 ust. 1 prawa autorskiego nie wymaga także, aby zgoda ta wyrażona została w formie pisem-

18 J. Sieńczyło-Chlabicz, Przedmiot, podmiot i charakter prawa do wizerunku, „Przegląd Ustawodawstwa Gospodarczego" 2003, nr 8, s. 17.

19 Media a dobra osobiste, red. J. Barta, R. Markiewicz, Warszawa 2009, s. 125.

20 Tak J. Barta, R. Markiewicz, A. Matlak, Prawo mediów, LexisNexis 2008 s. 453; J. Sieńczyło-Chlabicz, Rozpowszechnianie wizerunku, op. cit., s. 40; A. Karpowicz, Poradnik prawny dla ludzi twórczych, Warszawa 1995, s. 60.

${ }_{21}$ T. Grzeszak [w:] System prawa prywatnego, t. 13, op. cit., s. 675; K. Święcka, Okoliczności wyłączające bezprawność, Warszawa 2010, s. 68; J. Balcarczyk, Prawo do wizerunku i jego komercjalizacja, Warszawa 2009, s. 52-54.

22 P. Ślęzak, Ustawa o prawie autorskim, op. cit., s. 558.

23 P. Sobolewski [w:] Kodeks cywilny. Komentarz, op. cit.

24 Wyrok Sądu Apelacyjnego w Warszawie z 7 maja 2014 r., sygn. akt I ACa 1686/13, LEX nr 1500839. 
nej ${ }^{25}$. Jej udzielenie może nastąpić w każdej formie, a ustalenie faktu wyrażenia zgody na publikację wizerunku może nastąpić przy użyciu wszelkich środków dowodowych ${ }^{26}$. Uprawniony powinien wyrazić zgodę najpóźniej w chwili ustalenia wizerunku. Może to zatem zrobić przed ustaleniem wizerunku, jak również w czasie, kiedy wizerunek powstaje. Udzielenie zgody post factum nie wyłączy bezprawności ${ }^{27}$. Natomiast zgoda na rozpowszechnianie wizerunku powinna być udzielona, jak się wydaje, zanim osoba zainteresowana rozpowszechnianiem wizerunku podejmie działania zmierzające do jego upublicznienia ${ }^{28}$.

10. Tego typu zgoda często jest udzielana przez akceptację np. regulaminu danego wydarzenia czy zakupu biletów na wydarzenie. Zapisy takie znajdują się w regulaminach koncertów, zawodów sportowych i innych imprez masowych ${ }^{29}$. $\mathrm{W}$ takim wypadku istotne jest, aby regulamin był dostępny w taki sposób, by każdy uczestnik wydarzenia miał możliwość zapoznania się z jego treścią. Inną popularną i skuteczniejszą pod względem dowodowym, choć również znacznie trudniejszą organizacyjnie, metodą jest odebranie przedmiotowego oświadczenia od każdej uczestniczącej w wydarzeniu osoby, np. przez złożenie przez nią podpisu na przygotowanej wcześniej karcie zawierającej treść oświadczenia. Jeśli spotkanie z posłem nie ma takiego regulaminu, to konieczne jest posiadanie zgody od wszystkich uczestników spotkania na filmowanie (fotografowanie). Dlatego też konieczna jest wyraźna informacja, o tym, że spotkanie będzie nagrywane i rozpowszechnianie i że udział w spotkaniu jest jednoznaczny z wyrażeniem zgody przez uczestników na nagrywanie i rozpowszechnianie wizerunku (informacja taka powinna być także dostępna już w zapowiedziach o spotkaniu).

Także z punktu widzenia przepisów prawa prasowego publikowanie lub rozpowszechnianie $\mathrm{w}$ inny sposób informacji utrwalonych za pomocą zapisów fonicznych i wizualnych wymaga zgody osób udzielających informacji (art. 14 ust. 1). Omawiane przepisy chronią prawo do prywatności osób fotografowanych (filmowanych).

25 Należy dodać, że na gruncie przepisów RODO, o których zob. pkt 12 opinii, zgoda ta musi być uzyskana w formie możliwej do wykazania.

26 Wyrok Sądu Apelacyjnego w Warszawie z 17 lipca 2009 r., sygn. akt VI ACa 5/09, Legalis 924415.

27 P. Ślęzak, Ochrona prawa do wizerunku, Wydawnictwo Uniwersytetu Śląskiego, Katowice 2009, s. 35.

28 P. Ślęzak, Ustawa o prawie autorskim, op. cit., s. 567.

29 Np. regulamin uczestnictwa w wydarzeniach organizowanych przez Estradę Poznańską, http://www.estrada.poznan.pl/pages/regulamin--2 czy Regulamin Koncertów Twoje Koncerty PL, http://twojekoncerty.pl/regulamin-koncertow/ [dostęp 9 maja 2018 r.], z których wynika, że udział w wydarzeniach oznacza udzielenie nieodpłatnej zgody na nagrywanie, fotografowanie, filmowanie lub dokonywanie innego rodzaju zapisu wizerunku uczestnika oraz wykorzystywanie utrwalonego wizerunku. 
11. Wizerunek stanowić może także dobro osobiste w rozumieniu art. 23 i 24 k.c. ${ }^{30}$. Prawo do wizerunku w świetle art. 23 k.c. i art. 81 prawa autorskiego stanowi dobro osobiste, jednak do jego naruszenia może dojść w tych sytuacjach, gdy naruszone jest jednocześnie inne dobro osobiste, np. prawo do prywatności, cześć lub godność. Przyjmuje się przy tym, że naruszenie dobra osobistego może nastąpić wskutek takiej publikacji wizerunku, która umożliwia identyfikację osoby ${ }^{31}$. Podkreślić należy, że o naruszeniu prawa osobistego w postaci wizerunku osoby fizycznej (art. 23 k.c. w zbiegu z art. 81 prawa autorskiego) można mówić wówczas, gdyby nagranie (bez zgody osoby filmowanej) emitowane byłoby w sposób umożliwiający rozpoznanie tej osoby w sposób uniwersalny (powszechny) w dwojakim znaczeniu; nie ogranicza się tylko do wąskiego kręgu osób najbliższych i znajomych rozpoznanej osoby; po drugie, źródłem takiego rozpoznania powinien być już sam sposób ujęcia, pozwalający na identyfikację (ustalenie tożsamości) osoby sfotografowanej. W pozostałych przypadkach należy przyjmować brak możliwości rozpoznania (identyfikacji) osoby sfotografowanej (filmowanej) ${ }^{32}$.

12. W związku z wejściem w życie w dniu 25 maja 2018 r. ogólnego rozporządzenia o ochronie danych osobowych (RODO) - rozporządzenia Parlamentu Europejskiego i Rady (UE) 2016/679 z 27 kwietnia 2016 r. w sprawie ochrony osób fizycznych w związku z przetwarzaniem danych osobowych i w sprawie swobodnego przepływu takich danych oraz uchylenia dyrektywy 95/46/WE z 27 kwietnia 2016 r. (Dz.Urz. UE L 119, s. 1) powyższą opinię należy uzupełnić o następujące stwierdzenie:

$\mathrm{O}$ ile $\mathrm{z}$ punktu widzenia prawa autorskiego zgoda na wykorzystanie wizerunku może być udzielona $\mathrm{w}$ dowolnej formie, to $\mathrm{z}$ punktu widzenia RODO wizerunek osoby fizycznej jest daną osobową i w omawianym w opinii przypadku wymagana zgoda dla celów dowodowych powinna być udzielona na piśmie (administrator musi być w stanie wykazać, że osoba, której dane dotyczą, wyraziła zgodę na przetwarzanie swoich danych osobowych, zgodnie z art. 7 ust. 1 RODO). Ponadto zgoda na przetwarzanie danych osobowych powinna realizować tzw. obowiązek informacyjny, o którym mowa w art. 13 RODO, czyli zawierać klauzulę informacyjną o przetwarzaniu danych osobowych. Informacja o tym, że udział w spotkaniu z posłem jest równoznaczny z wyrażeniem zgody na rozpowszechnianie wizerunku utrwalonego podczas spotkania na określonych polach eksploatacji (np. strona www posła, portal społecznościowy, biuletyn informacyjny) i w określonych celach (np. cel informacyjny, promocyjny)

30 Dyskusja doktryny co do kwalifikacji wizerunku jako dobra osobistego została wyczerpująco przedstawiona w J. Balcarczyk, Prawo do wizerunku, op. cit.

31 Wyrok Sądu Apelacyjnego w Warszawie z 17 marca 2015 r., sygn. akt VI ACa 596/14, Legalis 1285004.

32 Wyrok Sądu Apelacyjnego w Warszawie z 12 września 2017 r., sygn. akt I ACa 1230/16, LEX nr 2402452. 
oraz klauzula informacyjna o przetwarzaniu danych osobowych musi być dostępna dla uczestników spotkania przed spotkaniem. Ponadto osoba, której dane dotyczą, ma prawo w dowolnym momencie wycofać zgodę. Wycofanie zgody nie wpływa na zgodność z prawem przetwarzania, którego dokonano na podstawie zgody przed jej wycofaniem. O tym także osoby uczestniczące w spotkaniu muszą zostać poinformowane.

\section{Podsumowanie}

W podsumowaniu należy powtórzyć wnioski sformułowane w wyniku poczynionych rozważań.

- Nie wymaga się zezwolenia na rozpowszechnianie wizerunku osoby, jeśli stanowi ona jedynie szczegół całości takiej jak zgromadzenie, krajobraz, publiczna impreza.

- Jeśli wizerunek osoby stanowi wyłącznie element akcydentalny lub akcesoryjny przedstawienia, czyli że w razie jego usunięcia nie zmieniłby się przedmiot i charakter przedstawienia, to rozpowszechnianie wizerunku nie wymaga zezwolenia.

- Nie jest wymagane zezwolenie na rozpowszechnianie wizerunku od osoby powszechnie znanej, jeśli wizerunek odnosi się do funkcji publicznych pełnionych przez tę osobę.

- Dozwolone jest publikowanie wizerunków spacerowiczów w parku, ludzi zgromadzonych w czasie manifestacji ulicznej, uczestników konferencji naukowej itp. Natomiast jeżeli dominantą kadru jest wizerunek konkretnej osoby (fotograf albo operator „skupiają się” na jednej osobie, eksponują ją), rozpowszechnianie wymaga zgody osoby przedstawionej w kadrze.

\section{Bibliografia}

Balcarczyk B., Prawo do wizerunku i jego komercjalizacja, Warszawa 2009.

Barta J., Markiewicz R., Matlak A., Prawo mediów, LexisNexis 2008.

Golat R., Zasady rozpowszechniania wizerunków pracowników, „Służba Pracownicza” 2009, nr 5(19).

Grzeszak T. [w:] System prawa prywatnego, t. 13, Prawo autorskie, red. J. Barta, Warszawa 2017.

Karpowicz A., Poradnik prawny dla ludzi twórczych, Warszawa 1995.

Media a dobra osobiste, red. J. Barta, R. Markiewicz, Warszawa 2009.

Prawo autorskie i prawa pokrewne. Komentarz, red. J. Barta, R. Markiewicz, 2011, LEX.

Sieńczyło-Chlabicz J., Naruszenie prywatności osób publicznych przez prasę, Warszawa 2012. 
Sieńczyło-Chlabicz J., Przedmiot, podmiot i charakter prawa do wizerunku, „Przegląd Ustawodawstwa Gospodarczego" 2003, nr 8.

Sieńczyło-Chlabicz J., Rozpowszechnianie wizerunku osób powszechnie znanych, „Przegląd Prawa Handlowego" 2003, nr 9.

Sobolewski P. [w:] Kodeks cywilny. Komentarz, red. K. Osajda, Warszawa 2018.

Ślęzak P., Ochrona prawa do wizerunku, Wydawnictwo Uniwersytetu Śląskiego, Katowice 2009.

Ślęzak P., Ustawa o prawie autorskim i prawach pokrewnych. Komentarz, Warszawa 2017. Święcka K., Okoliczności wyłączające bezprawność, Warszawa 2010. 